\title{
Effect of standardizing the lactose content of cheesemilk on the properties of low-moisture, part-skim Mozzarella cheese
}

\author{
A. C. Moynihan, ${ }^{*}$ S. Govindasamy-Lucey, $\dagger^{1}$ M. Molitor, $\dagger$ J. J. Jaeggi, $\dagger$ M. E. Johnson, $\dagger$ P. L. H. McSweeney, ${ }^{*}$ \\ and J. A. Lucey†‡ \\ ${ }^{*}$ School of Food and Nutritional Sciences, University College Cork, Cork, Ireland \\ †Wisconsin Center for Dairy Research, and \\ łDepartment of Food Science, University of Wisconsin-Madison, 1605 Linden Drive, Madison 53706
}

\begin{abstract}
The texture, functionality, and quality of Mozzarella cheese are affected by critical parameters such as $\mathrm{pH}$ and the rate of acidification. Acidification is typically controlled by the selection of starter culture and temperature used during cheesemaking, as well as techniques such as curd washing or whey dilution, to reduce the residual curd lactose content and decrease the potential for developed acidity. In this study, we explored an alternative approach: adjusting the initial lactose concentration in the milk before cheesemaking. We adjusted the concentration of substrate available to form lactic acid. We added water to decrease the lactose content of the milk, but this also decreased the protein content, so we used ultrafiltration to help maintain a constant protein concentration. We used 3 milks with different lactose-to-casein ratios: one at a high level, 1.8 (HLC, the normal level in milk); one at a medium level, 1.3 (MLC); and one at a low level, 1.0 (LLC). All milks had similar total casein (2.5\%) and fat $(2.5 \%)$ content. We investigated the composition, texture, and functional and sensory properties of low-moisture, part-skim Mozzarella manufactured from these milks when the cheeses were ripened at $4^{\circ} \mathrm{C}$ for $84 \mathrm{~d}$. All cheeses had similar $\mathrm{pH}$ values at draining and salting, resulting in cheeses with similar total calcium contents. Cheeses made with LLC milk had higher $\mathrm{pH}$ values than the other cheeses throughout ripening. Cheeses had similar moisture contents. The LLC and MLC cheeses had lower levels of lactose, galactose, lactic acid, and insoluble calcium compared with HLC cheese. The lactose-to-casein ratio had no effect on the levels of proteolysis. The LLC and MLC cheeses were
\end{abstract}

\footnotetext{
Received March 24, 2016.

Accepted June 15, 2016.

${ }^{1}$ Corresponding author: rani@cdr.wisc.edu
}

harder than the HLC cheese during ripening. Maximum loss tangent (LT), an index of cheese meltability, was lower for the LLC cheese until $28 \mathrm{~d}$ of ripening, but after $28 \mathrm{~d}$, all treatments exhibited similar maximum LT values. The temperature where $\mathrm{LT}=1$ (crossover temperature), an index of softening point during heating, was higher for MLC and LLC cheese at 56 and $84 \mathrm{~d}$ of ripening. The LLC cheese also had lower blister color and less stretch than MLC and HLC cheese. Adjusting the lactose content of milk while maintaining a constant casein level was a useful technique for controlling cheese $\mathrm{pH}$, which affected the texture, functionality, and sensory properties of low-moisture, part-skim Mozzarella cheese.

Key words: acidification, lactose, texture, lowmoisture part-skim Mozzarella

\section{INTRODUCTION}

A critical step in cheesemaking involves the fermentation of lactose to lactic acid by starter cultures. The extent of acidification at key steps in the process, such as cutting of the coagulum and $\mathrm{pH}$ at whey drainage, are critical parameters that affect cheese texture and quality (Lawrence et al., 1984, 1987; Lucey and Fox, 1993). The rate and extent of acidification influence many important cheese properties, such as moisture content, solubilization of calcium phosphate, rate of proteolysis during ripening, and functional attributes (Johnson and Lucey, 2006). Cheesemakers have developed many ways to modify the rate of acidification, including different types and amounts of starter cultures and cooking temperatures to modify fermentation activity. However, controlling the $\mathrm{pH}$ of the finished cheese can be difficult or problematic in pasta filata cheeses. The curd must reach a certain $\mathrm{pH}$ value at the point of whey drainage to be sufficiently pliable at the mixing/molding operation. The acidification rate in Mozzarella is often rapid and, in many industrial situations, it is difficult to process all the cheese through 
the mixer/molder in a short period. Thus, although the first curd through the mixer/molder might be at $\mathrm{pH} 5.3$ (ideal), the final curds might be run through much later and have $\mathrm{pH}$ values as low as 5.0. The functional and bake characteristics of cheeses made from these 2 curds will be markedly different.

Excessive fermentation of residual lactose during ripening (after the end of the manufacturing stage) increases the risk of producing an acidic cheese. Salt concentration can modify the extent of fermentation of residual lactose (Turner and Thomas, 1980). Cheese with $\mathrm{pH}$ values $<5.0$ are often described as short or brittle, poorly meltable, and often lacking in a typical cheese flavor profile (Lee et al., 2005). During cheesemaking, 2 commonly used approaches to control acidity involve trying to modify the amount of lactose in curd particles by washing or whey dilution. We wanted to explore an alternative approach in which we adjusted the initial lactose content of the cheesemilk rather than trying to vary the lactose content of curd particles. Previous studies have modified the lactose content of cheese by adding lactose powder to milk or whey or by curd washing to reduce lactose levels (Huffman and Kristoffersen, 1984; Shakeel-Ur-Rehman et al., 2004).

Curd washing involves the addition of water to the curd after whey drainage. Curd washing is widely used in cheese varieties such as Muenster, brick, and Colby, and has been intensively studied (Lee et al., 2005, 2010, 2011; Osaili et al., 2010; Hou et al., 2012, 2014a,b). Curd washing is usually done when the final desired $\mathrm{pH}$ has been attained, and washing can reduce the residual lactose content, preventing excessive acidification (which can negatively affect many textural attributes). Multiple parameters affect the degree of lactose removal from curd particles during the washing step, including particle size or contact area, method of washing, temperature of the water and curd, composition and structure of curd particles, and degree of agitation.

Another common approach used to modify lactose content during cheesemaking is whey dilution. This method is used in Gouda (Dutch-type) cheese and involves the removal of a portion of the whey (approximately $20-40 \%)$, replacing it with warm $\left(\sim 35^{\circ} \mathrm{C}\right)$ water.

We selected low-moisture, part-skim (LMPS) Mozzarella for this study because $\mathrm{pH}$ value has a major effect on its functional properties (Guinee et al., 2002; McMahon et al., 2005). The objective of this study was to investigate the effect of lactose-to-casein ratio of milk on the texture, functionality, and bake properties of LMPS Mozzarella cheese during ripening. To reduce the lactose-to-casein ratio, we added water to UF retentates (dilution with water could also affect soluble minerals, so this aspect was also investigated). We used
UF to produce cheesemilks with similar casein and fat content in all treatments.

\section{MATERIALS AND METHODS}

\section{Preparation of Milks}

Standardized milks with 3 different lactose-to-casein ratios were prepared: 1.8 (HLC), 1.3 (MLC), and 1.0 (LLC). The HLC ratio was similar to that of traditional LMPS Mozzarella cheesemilks. The UF process was carried out on 4 separate days over 1 mo to generate the 2 retentates (UF retentates 1 and 2) used to prepare the standardized milks for cheesemaking.

Raw cream and part-skim milk (2.3\% fat) were obtained from the University of Wisconsin-Madison dairy plant $2 \mathrm{~d}$ before cheesemaking. We performed UF at $<7^{\circ} \mathrm{C}$ by recirculating $1,500 \mathrm{~kg}$ of part-skim milk through a UF unit (modified APV North America Inc., Tonawanda, NY) fitted with 4 spiral-wound, polyethersulfone membranes (model ST3B4338, Synder Filtration, Vacaville, CA) to the feed tank until we obtained the desired composition. Each membrane had a molecular weight cut-off of 10,000 Da, and the total membrane area was $32.8 \mathrm{~m}^{2}$. The TS content was determined using Atago refractometers (models 10M and 20M, Atago Ltd., Tokyo, Japan) and by volume reduction. The UF process was stopped when the retentate and permeate reached TS levels of approximately 14.0 and $5 \%$, respectively. This retentate was named UF retentate 1 (Table 1), and part of it was transferred to another tank to be used to standardize milks. UF of the remaining retentate was continued until a total solids of about $16-17 \%$ was reached. Water purified by reverse osmosis (RO) was added to this retentate at a ratio of 3:7 to dilute the lactose contents, and this retentate was then called UF retentate 2 (Table 1 ). Both retentates were stored overnight at $4^{\circ} \mathrm{C}$ and blended to the appropriate lactose contents, specified casein contents $(2.5 \%)$, and casein-to-fat ratio the following morning to give standardized cheesemilks.

We produced milks with 3 different lactose levels by blending appropriate ingredients to obtain the desired lactose-to-casein ratios (Table 1). All milks were standardized to similar casein concentration $(2.5 \%)$ and fat content $(2.5 \%)$, as well as a casein-to-fat ratio of 1.0. The HLC cheesemilk was standardized by removing or adding cream. The MLC cheesemilk was standardized by blending UF retentate 1, cream, and permeate. The LLC cheesemilk was standardized by blending UF retentate 2, cream, and permeate. When necessary, we added RO water was added to milk to obtain the desired composition (Table 1). 
Table 1. Average composition (\% unless otherwise noted) and weights of part-skim milk, cream, ultrafiltered milk retentates (UF 1 with a normal lactose level, UF 2 with a lower lactose level), and permeate used to prepare standardized milk treatments with high (HLC), medium (MLC), and low (LLC) lactose-to-casein ratios ${ }^{1}$

\begin{tabular}{|c|c|c|c|c|c|c|}
\hline Variable & Part-skim milk & Cream & $\begin{array}{l}\text { UF milk } \\
\text { retentate } 1\end{array}$ & $\begin{array}{l}\text { UF milk } \\
\text { retentate } 2\end{array}$ & Permeate & $\begin{array}{c}\text { Reverse } \\
\text { osmosis } \\
\text { water }\end{array}$ \\
\hline \multicolumn{7}{|l|}{ Composition } \\
\hline Solids & $11.10(0.42)$ & $35.44(1.95)$ & $14.17(0.19)$ & $11.41(0.71)$ & $5.13(0.27)$ & - \\
\hline Total protein & $3.23(0.03)$ & $2.11(0.09)$ & $4.79(0.01)$ & $4.11(0.12)$ & $0.19(0.05)$ & - \\
\hline Casein & $2.44(0.02)$ & $1.54(0.11)$ & $3.68(0.02)$ & $3.18(0.09)$ & $0.04(0.04)$ & - \\
\hline \multicolumn{7}{|l|}{ Weight (\%) } \\
\hline $\mathrm{HLC}$ & 99.5 & 0.5 & - & - & - & - \\
\hline MLC & - & 0.9 & 66.9 & - & 9.3 & 22.9 \\
\hline LLC & - & 0.9 & - & 77.5 & 2.4 & 19.1 \\
\hline
\end{tabular}

${ }^{1}$ Values represent the means (SD) of 4 replicates for each treatment.

\section{Rennet Coagulation Properties}

Preliminary work demonstrated that MLC and LLC milks did not form sufficiently firm gels within $1 \mathrm{~h}$ after rennet addition, probably due to the addition of RO water to the milks and resulting in decreased $\mathrm{Ca}^{2+}$ activity. Rheological testing of rennet gels was undertaken for each cheese milk and the parameters. We varied temperature and $\mathrm{CaCl}_{2}$ addition to obtain similar time to reach storage modulus $\left(\mathbf{G}^{\prime}\right)$ values of 1 (onset of gelation) for all milks. We determined the rheological properties of each treatment using dynamic low-amplitude oscillatory rheometry as described previously by Govindasamy-Lucey et al. (2004). To obtain similar $\mathrm{G}^{\prime}$ profiles (results not shown), we selected renneting temperatures of 32,33 , and $34^{\circ} \mathrm{C}$ for HLC, MLC, and LLC milks, respectively, and added $\mathrm{CaCl}_{2}(0.01 \%$, wt/wt) to all milks.

\section{Cheese Manufacture}

Cheese making was performed at the University of Wisconsin-Madison dairy plant and was replicated on 4 separate days with at least 1 batch of each cheese made each day, for each treatment. Each day, a fresh batch of raw milk was processed and standardized to achieve the HLC, MLC, and LLC targets. Each milk treatment consisted of $272 \mathrm{~kg}$, which was pasteurized at $73^{\circ} \mathrm{C}$ for $19 \mathrm{~s}$ and cooled to the appropriate renneting temperature for each treatment as determined by rennet coagulation experiments; HLC, MLC, and LLC were renneted at 32,33 , and $34^{\circ} \mathrm{C}$, respectively. We added thermophilic cultures containing Streptococcus thermophilus and Lactobacillus helveticus (Tempo 303, Cargill Texturizing Solutions, Waukesha, WI) to each vat at a rate of $8.46 \mathrm{~g} / 100 \mathrm{~kg}$ of milk. We also added $\mathrm{CaCl}_{2}(0.01 \%$, wt/wt) to all vats. Before rennet addi- tion, the MLC and LLC cheese milks were given slightly longer starter ripening times (15 min longer) to allow for a small decrease in $\mathrm{pH}$, because these milks had a slightly higher $\mathrm{pH}$ than HLC milk. This adjustment allowed us to maintain a similar $\mathrm{pH}$ at rennet addition ( $\mathrm{pH}$ 6.6) for all milks. After this ripening period, we added fermentation-produced calf chymosin (Chy-Max Extra, 630 international milk clotting units/mL, Chr. Hansen Inc., Milwaukee, WI) to each vat at a level of 0.05 international milk clotting units $/ \mathrm{mL}$ of milk. The coagulum of each vat was cut based on a prescribed time to ensure constant inoculation to cut time for each vat: HLC was cut at $45 \mathrm{~min}, \mathrm{MLC}$ was cut at $30 \mathrm{~min}$, and LLC was cut at $35 \mathrm{~min}$. All coagula were cut with $1.9-\mathrm{cm}$ knives. The temperature of the curd and whey slurry was raised to $41^{\circ} \mathrm{C}$ over $30 \mathrm{~min}$, and then held for $40 \mathrm{~min}$ until the $\mathrm{pH}$ of the curd reached $\sim 5.90$. The curd was then trenched and the whey drained. At a curd $\mathrm{pH}$ of 5.2 , all curds were milled and presalted at $0.28 \%$ (wt/wt, based on the weight of cheesemilk) and stretched in a cooker (Supreme 640 Pasta Filata Mixer, Stainless Steel Fabricating Inc., Columbus, WI) for about $7 \mathrm{~min}$. The maximum temperature reached by the curd was $\sim 54^{\circ} \mathrm{C}$. After stretching, the curd was placed in 2.3-kg blocks, kept in cold water for $45 \mathrm{~min}$ and then brined for $135 \mathrm{~min}$ at $\sim 10^{\circ} \mathrm{C}$ in saturated brine (25\% salt brine). The brine-salted cheeses were vacuum-packed and stored at $4^{\circ} \mathrm{C}$ for $84 \mathrm{~d}$. Analysis was carried out on cheese at 1, 14, 28, 42, 56, and $84 \mathrm{~d}$ of ripening.

\section{Compositional Analysis and Proteolysis}

All compositional analyses were carried out in triplicate. Milk samples were analyzed for fat by Mojonnier (AOAC International, 2000), protein (total percentage $\mathrm{N} \times 6.38$ ) by Kjeldahl (AOAC International, 2000), ca- 
sein (AOAC International, 2000), lactose (AOAC International, 2000), TS (Green and Park, 1980), and NPN (AOAC International, 2000). Buffering was determined by the acid-base titration method (Lucey et al., 1993).

Cheese was analyzed for moisture (Marshall, 1992), fat by Mojonnier (AOAC International, 2000), protein by Kjeldahl (AOAC International, 2000), salt by chloride electrode method (MK II Chloride analyzer 926; Nelson and Jameson Inc., Marshfield, WI; Johnson and Olson 1985), and lactose, galactose and lactic acid using the HPLC method (Zeppa et al., 2001). Cheese composition was measured at $\mathrm{d} 14$. Cheese $\mathrm{pH}$ was measured at 1, 14, 28, 42, 56 and $84 \mathrm{~d}$ using a spear-tip $\mathrm{pH}$ probe (accuCap Capillary Junction $\mathrm{pH}$ combination electrode 13-620-133; Fisher Scientific, Itasca, IL) inserted directly into the cheese. Acid-base titration (Hassan et al., 2004) was performed to measure the insoluble calcium (INSOL Ca) content of cheese at $1 \mathrm{~d}$, $2 \mathrm{wk}$, and $4 \mathrm{wk}$. Total calcium levels were measured in milk, rennet whey, and cheese (14 d) using inductively coupled plasma emission spectroscopy (Vista-MPX Simultaneous ICP-OES; Varian Inc., Palo Alto, CA; Govindasamy-Lucey et al., 2007). All analyses were done in triplicate.

Proteolysis was determined by measuring levels of $\mathrm{pH}$ 4.6-soluble N (Kuchroo and Fox, 1982) and N content determined by AOAC International (2000). Proteolysis was measured at 1,28 , and $56 \mathrm{~d}$ of ripening.

\section{Texture Profile Analysis}

Cheese was cut into cylindrical samples $(16 \mathrm{~mm}$ diameter, $17.5 \mathrm{~mm}$ height) using a Hobart slicer and steel cork borer. Samples were stored overnight at $4^{\circ} \mathrm{C}$ until compression by texture profile analysis (TPA) performed using a Texture Analyzer TA-XT2 (Stable Micro Systems, Godalming, UK). The TPA was performed by compressing samples to $80 \%$ of their original height; chewiness and hardness were calculated as described by Bourne (1978).

\section{Dynamic Small-Amplitude Oscillatory Rheology}

Cheese samples were sliced on a Hobart slicer to $\sim 2.3 \mathrm{~mm}$ and cut into discs $50 \mathrm{~mm}$ in diameter using a cork borer. Samples were then stored in a refrigerator at $4^{\circ} \mathrm{C}$ at least $8 \mathrm{~h}$ before analysis. We measured the rheological properties of the cheese with a Paar Physica Universal Dynamic Spectrometer (UDS 200; Physica Messtechnik, Stuttgart, Germany) as described by Lucey et al. (2005). Samples were heated from 5 to $85^{\circ} \mathrm{C}$ at $1^{\circ} \mathrm{C} / \mathrm{min}$ on a $50-\mathrm{mm}$ serrated parallel plate and subjected to a strain of $0.5 \%$ at a frequency of $0.08 \mathrm{~Hz}$. During heating, the parameters measured were
$\mathrm{G}^{\prime}$, loss modulus $\left(\mathbf{G}^{\prime \prime}\right)$, and loss tangent $(\mathbf{L T})$. We also recorded the maximum LT $\left(\mathbf{L} \mathbf{T}_{\max }\right)$, the temperature at which the $\mathbf{L T}_{\max }$ occurred (TLT), and the temperature at which $\mathrm{LT}=1$ (i.e., where $\mathrm{G}^{\prime \prime}=\mathrm{G}^{\prime}$ ), because this indicates the transition from a solid to a liquid-like system (i.e., a crossover point).

\section{Descriptive Sensory Analysis}

The trained ( $>20 \mathrm{~h}$ of training) Wisconsin Center for Dairy Research sensory panel consisting of at least 12 members used a mixture of sensory Spectrum and quantitative descriptive analysis (Meilgaard et al., 1999) to evaluate the textural and flavor properties of the unmelted and melted cheese as described by Chen et al. (2009) and Moynihan et al. (2014). The numerical intensity scale ranged from 0 to 15 , with reference points as described by Moynihan et al. (2014). Each cheese was given a random 3-digit code and assessed in duplicate on 2 separate days. Cheese cubes were tempered at $\sim 12^{\circ} \mathrm{C}$ before assessment for texture and flavor attributes (acidity, saltiness, and butteriness). Textural attributes evaluated were firmness and adhesiveness of mass.

Cheeses were shredded, added to pizza crust, and baked in a forced-air commercial oven (Impinger Ovens, Lincoln Foodservice Products Inc., Ford Wayne, IN) at $260^{\circ} \mathrm{C}$ for $5 \mathrm{~min}$ as described by Moynihan et al. (2014). The surface characteristics (free oil release, blister color, blister quantity, and skinning), stretch characteristics (strand length and strand thickness of stretched cheese), texture (hardness, chewiness, and cohesiveness of mass) were evaluated after cooling to $63^{\circ} \mathrm{C}$, and flavor attributes (acid and salt intensities after cooling to $63^{\circ} \mathrm{C}$ ) of the melted cheeses were evaluated as described by Moynihan et al. (2014).

\section{Experimental Design and Statistical Analysis}

Each treatment was replicated 4 times on 4 separate days each, with freshly prepared milk. We used a completely randomized design for analysis of the response variables relating to milk and cheese composition. We carried out ANOVA using the PROC GLM procedure of SAS (version 9.1; SAS Institute, 2004). We used Duncan's multiple comparison test to evaluate differences in the treatments; differences between means were considered significant at $P<0.05$.

The PROC MIXED procedure for repeated measurements of the SAS software package (SAS Inst. Inc., Cary, NC) was used to evaluate the effects of differing lactose-to-casein ratios and ripening times and their interactions on $\mathrm{pH}$, INSOL Ca, proteolysis, and functional, textural, and sensory properties. The mean 
Table 2. Composition of milks used to manufacture low-moisture, part-skim Mozzarella cheese; milks had high (HLC), medium (MLC), and low (LLC) lactose-to-casein ratios ${ }^{1}$

\begin{tabular}{|c|c|c|c|c|c|}
\hline \multirow[b]{2}{*}{ Variable } & \multicolumn{3}{|c|}{ Treatment $^{2}$} & \multirow[b]{2}{*}{ SEM } & \multirow[b]{2}{*}{$P$-value } \\
\hline & HLC & MLC & LLC & & \\
\hline $\begin{array}{l}\text { Lactose }(\%) \\
\text { TS }(\%) \\
\text { Fat }(\%) \\
\text { Total protein }{ }^{3}(\%) \\
\text { True protein }^{4}(\%) \\
\text { Casein }^{5}(\%) \\
\text { Casein:total protein (\%) } \\
\text { Casein:true protein (\%) } \\
\text { Casein:fat } \\
\text { Lactose:casein } \\
\text { Lactose:TS } \\
\text { NPN (\%) } \\
\text { Whey protein }{ }^{6}(\%) \\
\text { Total calcium }(\mathrm{mg} / 100 \mathrm{~g}) \\
\text { Calcium:protein (mg/g) } \\
\text { Calcium:casein }(\mathrm{mg} / \mathrm{g}) \\
\text { Buffering area } \\
\text { pH at max buffering peak }\end{array}$ & $\begin{array}{c}4.42^{\mathrm{c}} \\
10.90^{\mathrm{b}} \\
2.51^{\mathrm{a}} \\
3.24^{\mathrm{a}} \\
3.06^{\mathrm{a}} \\
2.50^{\mathrm{a}} \\
77.15^{\mathrm{a}} \\
81.51^{\mathrm{ab}} \\
1.00^{\mathrm{a}} \\
1.77^{\mathrm{c}} \\
0.41^{\mathrm{c}} \\
0.028^{\mathrm{c}} \\
0.57^{\mathrm{a}} \\
121^{\mathrm{c}} \\
37.48^{\mathrm{c}} \\
48.58^{\mathrm{c}} \\
0.030^{\mathrm{b}} \\
5.05^{\mathrm{a}}\end{array}$ & $\begin{array}{l}3.27^{\mathrm{b}} \\
10.21^{\mathrm{b}} \\
2.42^{\mathrm{a}} \\
3.18^{\mathrm{a}} \\
3.05^{\mathrm{a}} \\
2.47^{\mathrm{a}} \\
77.61^{\mathrm{a}} \\
81.03^{\mathrm{a}} \\
1.02^{\mathrm{a}} \\
1.32^{\mathrm{b}} \\
0.32^{\mathrm{b}} \\
0.021^{\mathrm{b}} \\
0.58^{\mathrm{a}} \\
115^{\mathrm{b}} \\
36.19^{\mathrm{b}} \\
46.63^{\mathrm{b}} \\
0.029^{\mathrm{ab}} \\
5.07^{\mathrm{a}}\end{array}$ & $\begin{array}{c}2.59^{\mathrm{a}} \\
9.15^{\mathrm{a}} \\
2.44^{\mathrm{a}} \\
3.19^{\mathrm{a}} \\
3.09^{\mathrm{a}} \\
2.53^{\mathrm{a}} \\
79.30^{\mathrm{b}} \\
82.02^{\mathrm{b}} \\
1.04^{\mathrm{a}} \\
1.02^{\mathrm{a}} \\
0.28^{\mathrm{a}} \\
0.017^{\mathrm{a}} \\
0.56^{\mathrm{a}} \\
102^{\mathrm{a}} \\
31.98^{\mathrm{a}} \\
40.33^{\mathrm{a}} \\
0.028^{\mathrm{a}} \\
5.13^{\mathrm{b}}\end{array}$ & $\begin{array}{l}0.050 \\
0.259 \\
0.022 \\
0.024 \\
0.025 \\
0.022 \\
0.182 \\
0.164 \\
0.012 \\
0.024 \\
0.011 \\
0.0005 \\
0.006 \\
1.658 \\
0.391 \\
0.507 \\
0.0004 \\
0.0166\end{array}$ & $\begin{array}{c}<0.0001 \\
0.0032 \\
\mathrm{NS} \\
\mathrm{NS} \\
\mathrm{NS} \\
\mathrm{NS} \\
<0.0001 \\
0.0071 \\
\mathrm{NS} \\
<0.0001 \\
0.0025 \\
<0.0001 \\
\mathrm{NS} \\
<0.0001 \\
<0.0001 \\
<0.0001 \\
0.0166 \\
0.0157\end{array}$ \\
\hline \multicolumn{6}{|c|}{${ }^{\mathrm{a}-\mathrm{c}}$ Means in the same row with a different superscript differ $(P<0.05)$. } \\
\hline \multicolumn{6}{|c|}{$\begin{array}{l}{ }^{2} \text { The means of the } 3 \text { main treatments (different lactose-to-casein ratios: HLC, MLC, LLC) were analyzed usin } \\
\text { the ANOVA of PROC GLM in SAS (version 9.1; SAS Institute, 2004). Duncan's multiple-comparison test wa } \\
\text { used to evaluate differences in the treatments at a significance level of } P<0.05 \text {. } \\
{ }^{3} \text { Total } \% \text { nitrogen } \times 6.38 \text {. } \\
{ }^{4} \text { (Total \% nitrogen }-\% \text { NPN) } \times 6.38 \text {. } \\
\text { (Total \% nitrogen }-\% \text { noncasein nitrogen) } \times 6.38 \text {. } \\
6 \text { True protein - casein. }\end{array}$} \\
\hline
\end{tabular}

squares for cheese, nested within treatment, was used as the random error term to test for significant differences.

\section{RESULTS AND DISCUSSION}

\section{Milk Composition}

In preliminary studies, when the same manufacturing protocol was used for all the cheeses, the moisture content of the LLC and MLC cheeses (49\%) were higher than those of the HLC ( $\sim 46$ to $47 \%$, data not shown). The cheese manufacturing protocol for the LLC and MLC cheese was then modified (by cutting the coagula at 35 and 30 min after rennet addition compared with $45 \mathrm{~min}$ for the HLC treatment) to decrease the moisture content. The composition of cheese milks is shown in Table 2. Milks had similar $(P>0.05)$ fat, total protein, true protein, casein, and whey protein contents. Lactose, TS, and lactose-to-casein ratio were significantly different between all treatments (as expected). The ratios of casein to total protein and casein to true protein were significantly higher for LLC cheesemilks than for the other treatments. This was due to the low NPN level in the LLC sample as the result of UF, where
NPN can readily permeate the UF membrane. The total Ca content in milks decreased with the lactoseto-casein ratio, probably due to the removal of some soluble Ca during UF and RO water addition. Ferrer et al. (2011) during UF observed a similar trend of decreased calcium-to-protein levels.

We also determined the buffering peak area in the vicinity of $\mathrm{pH} 5.0$ during acidification. This buffering peak is related to the amount of INSOL Ca phosphate in milk (Lucey et al., 1993). We observed significant $(P$ $<0.05$ ) differences between treatments, with a smaller buffering area (close to this buffering peak) in the LLC milk (Table 2). The $\mathrm{pH}$ where the maximum buffering index occurred during acid-base titrations was significantly $(P<0.05)$ higher in LLC milk.

\section{Cheese Composition and Proteolysis}

Mozzarella cheeses had similar $(P>0.05)$ moisture, salt, moisture in nonfat substance, and salt-in-moisture levels (Table 3). Small differences were observed for contents of fat, protein, and fat in DM, but all cheeses had compositions within the typical range of values expected for LMPS Mozzarella (Kindstedt et al., 1995; 
Table 3. Composition (at d 14) of low-moisture, part-skim Mozzarella cheese manufactured from milks with varying lactose-to-casein ratios; milks had high (HLC), medium (MLC), and low (LLC) lactose-to-casein ratios ${ }^{1}$

\begin{tabular}{|c|c|c|c|c|c|}
\hline \multirow[b]{2}{*}{ Variable } & \multicolumn{3}{|c|}{ Treatment $^{2}$} & \multirow[b]{2}{*}{ SEM } & \multirow[b]{2}{*}{$P$-value } \\
\hline & HLC & MLC & LLC & & \\
\hline Salt $(\%)$ & $1.86^{\mathrm{a}}$ & $1.62^{\mathrm{a}}$ & $1.86^{\mathrm{a}}$ & 0.083 & NS \\
\hline Protein $^{3}(\%)$ & $25.40^{\mathrm{a}}$ & $26.45^{\mathrm{b}}$ & $26.90^{\mathrm{c}}$ & 0.130 & $<0.0001$ \\
\hline Moisture in nonfat substance of cheese & $59.71^{\mathrm{a}}$ & $59.34^{\mathrm{a}}$ & $59.34^{\mathrm{a}}$ & 0.184 & NS \\
\hline Total calcium (mg/100 g) & $792^{\mathrm{a}}$ & $782^{\mathrm{a}}$ & $781^{\mathrm{a}}$ & 17.672 & NS \\
\hline Calcium:protein $(\mathrm{mg} / \mathrm{g})$ & $31.16^{\mathrm{b}}$ & $29.55^{\mathrm{ab}}$ & $29.03^{\mathrm{a}}$ & 0.595 & 0.05 \\
\hline Lactose at $42 \mathrm{~d}(\%)$ & $0.03^{\mathrm{c}}$ & $0.01^{\mathrm{b}}$ & $0.00^{\mathrm{a}}$ & 0.002 & 0.0001 \\
\hline Galactose at $42 \mathrm{~d}(\%)$ & $0.66^{\mathrm{c}}$ & $0.53^{\mathrm{b}}$ & $0.40^{\mathrm{a}}$ & 0.007 & $<0.0001$ \\
\hline \multicolumn{6}{|l|}{ Insoluble calcium ${ }^{4}$ (mg/g of protein) } \\
\hline at $1 \mathrm{~d}$ & $29.48^{\mathrm{a}, \mathrm{A}}$ & $27.71^{\mathrm{b}, \mathrm{A}}$ & $27.58^{\mathrm{b}, \mathrm{A}}$ & - & - \\
\hline at $14 \mathrm{~d}$ & $27.19^{\mathrm{a}, \mathrm{A}}$ & $27.01^{\mathrm{a}, \mathrm{A}}$ & $24.90^{\mathrm{b}, \mathrm{B}}$ & - & - \\
\hline
\end{tabular}

${ }^{\mathrm{a}-\mathrm{c}}$ Means within the same row not sharing a common superscript differ $(P<0.05)$.

${ }^{\mathrm{A}, \mathrm{B}}$ Means within the same column not sharing a common superscript differ $(P<0.05)$.

${ }^{1}$ Values represent the means of 4 replicates for each treatment.

${ }^{2}$ The means of the 3 main treatments (HLC, MLC, LLC) were analyzed using ANOVA in the PROC GLM procedure in SAS (version 9.1; SAS Institute, 2004). Duncan's multiple-comparison test was used to evaluate differences in treatments at a significance level of $P<0.05$.

${ }^{3}$ Total $\%$ nitrogen $\times 6.38$.

${ }^{4}$ The effects of the 3 treatments (HLC, MLC, and LLC), time of aging (A), and their interactions $(\mathrm{A} \times \mathrm{T})$ on the amount of insoluble calcium $(\mathrm{mg} / \mathrm{g}$ of protein) in the cheeses were analyzed using the MIXED procedure for repeated measurement in SAS (version 9.1; SAS Institute, 2004; Table 4).

Moynihan et al., 2014). Retention of fat depends on relative rigidity and the structure of the network at cutting (Johnson et al., 2001). The higher renneting temperatures $\left(34^{\circ} \mathrm{C}\right)$ used for the LLC milk could have contributed to a network that more easily lost fat during cutting and cooking (Mishra et al., 2005).

We observed no differences $(P>0.05)$ in total $\mathrm{Ca}$ levels between any of the cheese treatments, even though the total $\mathrm{Ca}$ in the milk was significantly different (Table 2). The critical $\mathrm{pH}$ values during cheesemaking were similar in all treatments, and differences in $\mathrm{pH}$ values can cause a change in the $\mathrm{Ca}$ content of cheese (Lucey and Fox, 1993). The calcium-to-protein level in the LLC cheese was slightly lower than that of the HLC cheese (Table 3). This presumably reflected the slightly higher protein content in the LLC cheese.

By 42 d of ripening, we observed almost no residual lactose in any cheese (Table 3$)$. The levels of galactose in the cheeses were significantly $(P<0.05)$ different (Table 3). The LLC cheese had the lowest galactose levels $(0.40 \%)$, and HLC cheese had the highest $(0.66 \%)$ (Table 3). The thermophilic cultures used for cheesemaking do not readily ferment the galactose moiety of lactose, so it accumulated in the cheese (Johnson and Olson, 1985). The higher galactose levels in the HLC cheese reflected the higher initial lactose concentration (starting substrate) in this cheesemilk.
Lactic acid levels in the cheese were significantly affected by the lactose-to-casein ratio (Table 4). The lactic acid concentration in cheese as a function of ripening time is shown in Figure 1a. At the start of ripening (1 d), LLC cheese had significantly lower lactic acid levels than MLC and HLC cheese, consistent with the lowest lactose levels in the LLC milk (Table 2). We observed a significant increase in lactic acid for all treatments between 1 and $14 \mathrm{~d}$ of ripening, presumably reflecting the fermentation of residual lactose. At $42 \mathrm{~d}$ of ripening, the LLC cheese still had the lowest lactic acid levels.

The $\mathrm{pH}$ values of cheese were also significantly affected by the lactose-to-casein ratio (Table 4). The $\mathrm{pH}$ trends during ripening (Figure 1b) were in agreement with the lactic acid concentrations (Figure 1a). The LLC cheese had significantly higher $\mathrm{pH}$ values throughout ripening than HLC and MLC cheeses due to its lower lactic acid levels.

The INSOL Ca phosphate content of cheese was significantly affected by the lactose-to-casein ratio (Table 4). Calcium is an important structural element of cheese that is primarily associated with casein (protein; Lucey and Fox, 1993), so INSOL Ca was expressed as milligrams of INSOL Ca per gram of protein (Lee et al., 2005). The MLC and LLC cheeses had significantly lower INSOL Ca-to-protein contents at $1 \mathrm{~d}$ of ripen- 
ing than HLC cheese (Table 3). Greater INSOL Ca losses in the LLC cheese (Table 2) presumably reflected some losses of soluble $\mathrm{Ca}$ in the UF permeate ( $\mathrm{Li}$ and Corredig, 2014) and dilution of milk by addition of RO water, which was used for the LLC treatments. It was likely that the losses of soluble Ca in the LLC and MLC milk samples caused a shift of some INSOL Ca phosphate into the serum phase of the cheese to attain or re-establish equilibrium. Lee et al. (2005) also observed greater solubilization of INSOL Ca during cheese ripening as a result of a curd washing step that removed some soluble Ca. Cheese $\mathrm{pH}$ values during ripening depend on 2 major factors: lactic acid levels and buffering due to the solubilization of INSOL Ca phosphate (Hassan et al., 2004). The significant increase in the $\mathrm{pH}$ of the LLC cheese during ripening (Figure 1b) was therefore likely due to its low lactic acid concentration (Figure

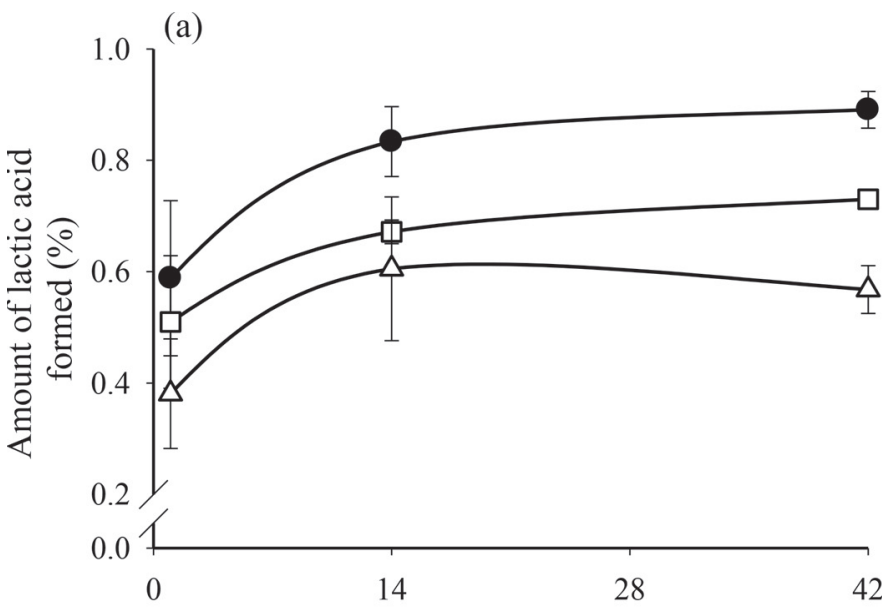

(b)

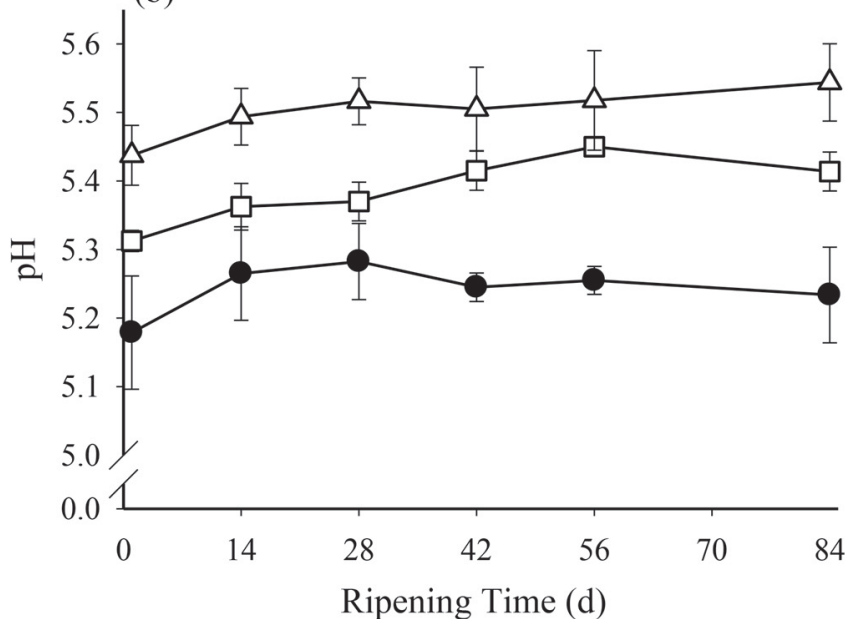

Figure 1. Lactic acid (a) and cheese $\mathrm{pH}$ (b) values as a function of ripening time of low-moisture, part-skim Mozzarella cheeses stored at $4^{\circ} \mathrm{C}$ made from milks with varying lactose-to-casein ratios: high 1.8 $(\bullet)$, medium $1.3(\square)$, and low $1.0(\Delta)$. Values are means of 4 replicates; vertical bars represent SD.

Journal of Dairy Science Vol. 99 No. 10, 2016 
Table 5. Degrees of freedom, statistical significance ( $P$-values), and $\mathrm{R}^{2}$ values for sensory properties of unmelted and melted cheese during ripening of low-moisture, part-skim Mozzarella cheese manufactured from milks with different lactose-to-casein ratios

\begin{tabular}{|c|c|c|c|c|c|c|c|c|c|}
\hline \multirow[b]{2}{*}{ Factor $^{1}$} & \multirow[b]{2}{*}{$\mathrm{df}$} & \multicolumn{3}{|c|}{ Unmelted cheese, $P$-value } & \multicolumn{5}{|c|}{ Melted cheese, $P$-value } \\
\hline & & Firmness & $\begin{array}{c}\text { Adhesiveness } \\
\text { of mass }\end{array}$ & Acid & $\begin{array}{l}\text { Blister } \\
\text { color }\end{array}$ & Chewiness & Hardness & Acid & $\begin{array}{l}\text { Strand } \\
\text { length }\end{array}$ \\
\hline Treatment $(\mathrm{T})$ & 2 & 0.006 & 0.002 & 0.036 & $<0.0001$ & 0.205 & 0.400 & 0.001 & 0.005 \\
\hline Age $(\mathrm{A})$ & 3 & $<0.0001$ & $<0.0001$ & 0.014 & 0.019 & 0.074 & $<0.0001$ & 0.123 & $<0.0001$ \\
\hline $\mathrm{A} \times \mathrm{T}$ & 6 & 0.052 & 0.191 & 0.137 & 0.330 & 0.016 & 0.106 & 0.760 & 0.674 \\
\hline $\mathrm{R}^{2}$ & & 0.94 & 0.82 & 0.71 & 0.89 & 0.64 & 0.90 & 0.70 & 0.80 \\
\hline
\end{tabular}

${ }^{1}$ Effects of the 3 treatments (high, medium, and low lactose-to-casein ratios), time of aging $(\mathrm{A})$, and their interactions $(\mathrm{A} \times \mathrm{T})$ on cheese properties were evaluated using the MIXED procedure for repeated measurement in SAS (version 9.1; SAS Institute, 2004). We used mean squares, nested within treatment, as the random error term to test for significant differences.

1a) and the large amount of solubilization of INSOL Ca phosphate (Table 3), which increases pH (due to buffering by the released phosphate ions).
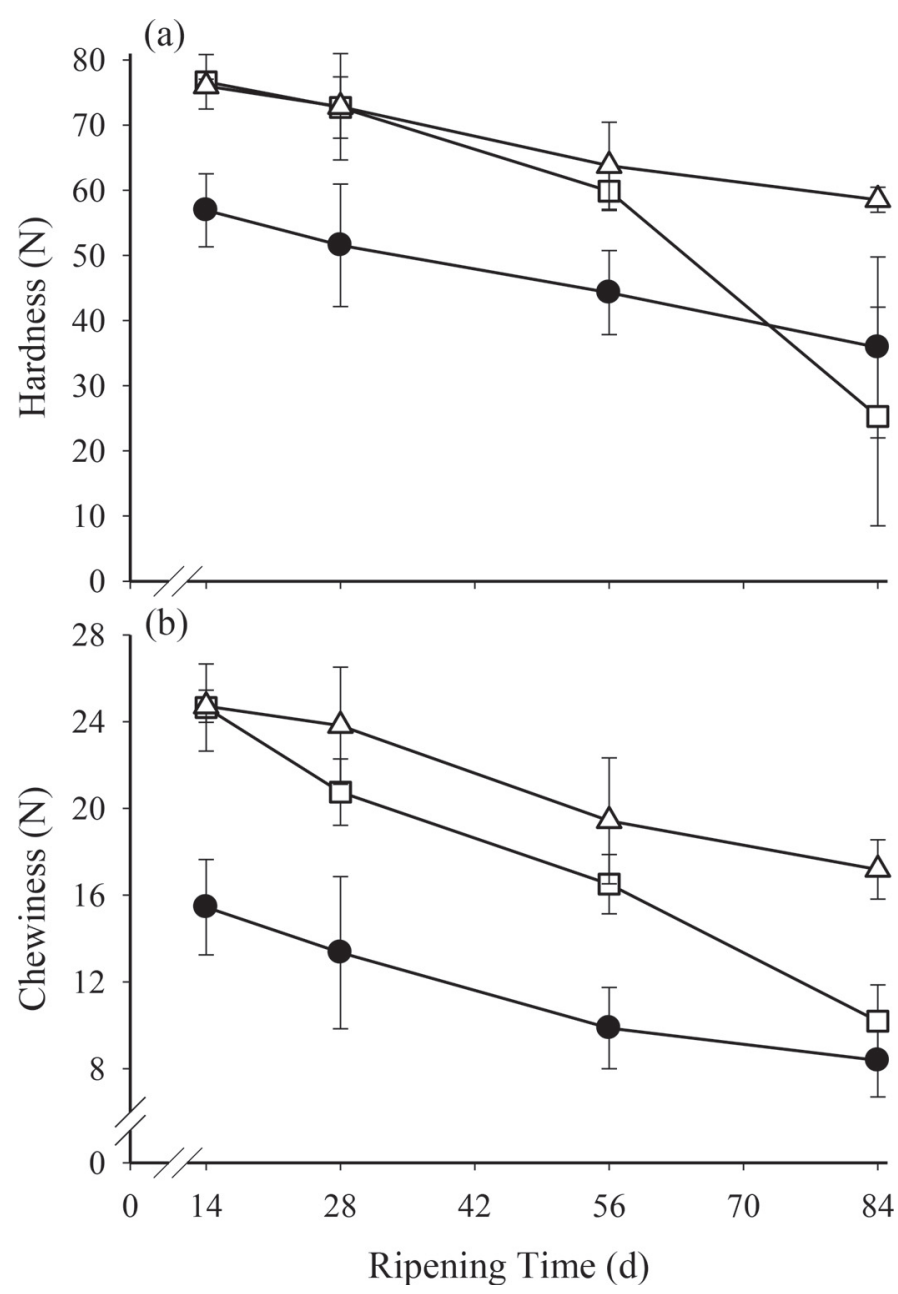

Figure 2. Texture profile analysis hardness (a) and chewiness (b) values as a function of ripening time of low-moisture, part-skim Mozzarella cheeses stored at $4^{\circ} \mathrm{C}$ made with milk of varying lactose-tocasein ratios: high $1.8(\bullet)$, medium $1.3(\square)$, and low $1.0(\Delta)$. Values are means of 4 replicates; vertical bars represent SD.
Varying the lactose-to-casein ratio levels in milk had no effect on $\mathrm{pH} 4$.6-soluble N:total $\mathrm{N}$ of LMPS Mozzarella cheese (Table 4), which is an index of proteolysis (Sousa et al., 2001) (Table 4). As expected, proteolysis increased during aging (Table 4). The level of protein was slightly higher $(\sim 1 \%)$ in MLC and LLC cheese than in HLC cheese, but the rate of proteolysis was not affected. This was probably due to the similar rennet-to-casein levels in the cheesemilks used in all our treatments (Govindasamy-Lucey et al., 2005).

\section{Unmelted Cheese Texture and Sensory Properties}

The lactose-to-casein ratio of milk significantly affected the instrumental TPA hardness (Table 4) and sensory firmness (Table 5) of the cheeses. The TPA hardness and chewiness values during ripening are shown in Figure 2. The MLC and LLC cheese had significantly higher TPA hardness and chewiness values than the HLC cheese during most of the ripening period (Figure 2). All cheeses exhibited a significant decrease in hardness and chewiness during ripening, reflecting the effect of proteolysis and solubilization of INSOL Ca phosphate (Lucey et al., 2003). We observed no significant $(P>0.05)$ difference in proteolysis levels between treatments (Table 4). The higher firmness/hardness and chewiness values of the LLC cheese during ripening were likely due to its higher $\mathrm{pH}$ value (Figure 1b) and not its INSOL Ca phosphate concentration, which was significantly lower than the HLC cheese (Table 3). Everard et al. (2006) found that a higher $\mathrm{pH}$ in Cheddar was correlated with increased chewiness and firmness. Ramkumar et al. (1998) found that curd showed an increased solid-like behavior at a higher $\mathrm{pH}$. Watkinson et al. (2001) also found that cheese firmness increased with higher $\mathrm{pH}$ values.

All unmelted cheese sensory properties measured were significantly affected by age (Table 5), with cheeses becoming less firm and more adhesive with age (Table 6). In agreement with the TPA hardness 
Table 6. Age-related changes in the sensory properties of unmelted low-moisture, part-skim Mozzarella cheese manufactured from milks with high (HLC), medium (MLC), and low (LLC) lactose-to-casein ratios during the 84-d ripening period ${ }^{1}$

\begin{tabular}{lllll}
\hline & & \multicolumn{3}{c}{ Treatment } \\
\cline { 3 - 4 } Attribute & $\begin{array}{c}\text { Ripening } \\
\text { time }(\mathrm{d})\end{array}$ & HLC & MLC & LLC \\
\hline Firmness & 14 & $8.62^{\mathrm{a}, \mathrm{A}}$ & $9.95^{\mathrm{b}, \mathrm{A}}$ & $9.70^{\mathrm{b}, \mathrm{A}}$ \\
& 28 & $8.53^{\mathrm{a}, \mathrm{A}}$ & $9.84^{\mathrm{c}, \mathrm{A}}$ & $9.17^{\mathrm{b}, \mathrm{B}}$ \\
& 56 & $7.77^{\mathrm{a}, \mathrm{B}}$ & $9.14^{\mathrm{b}, \mathrm{B}}$ & $8.72^{\mathrm{b}, \mathrm{BC}}$ \\
Adhesiveness of mass & 84 & $6.37^{\mathrm{a}, \mathrm{C}}$ & $7.95^{\mathrm{b}, \mathrm{C}}$ & $8.25^{\mathrm{b}, \mathrm{C}}$ \\
& 14 & $2.25^{\mathrm{a}, \mathrm{A}}$ & $1.60^{\mathrm{a}, \mathrm{A}}$ & $1.95^{\mathrm{a}, \mathrm{A}}$ \\
& 28 & $2.47^{\mathrm{a}, \mathrm{A}}$ & $2.04^{\mathrm{a}, \mathrm{AB}}$ & $1.78^{\mathrm{a}, \mathrm{A}}$ \\
Acid flavor intensity & 56 & $2.80^{\mathrm{b}, \mathrm{A}}$ & $2.36^{\mathrm{ab}, \mathrm{BC}}$ & $2.04^{\mathrm{a}, \mathrm{A}}$ \\
& 84 & $4.41^{\mathrm{b}, \mathrm{B}}$ & $2.94^{\mathrm{a}, \mathrm{C}}$ & $3.01^{\mathrm{a}, \mathrm{B}}$ \\
& 14 & $5.34^{\mathrm{b}, \mathrm{A}}$ & $4.85^{\mathrm{a}, \mathrm{A}}$ & $4.78^{\mathrm{a}, \mathrm{A}}$ \\
& 28 & $5.30^{\mathrm{a}, \mathrm{A}}$ & $5.21^{\mathrm{a}, \mathrm{AB}}$ & $5.17^{\mathrm{a}, \mathrm{B}}$ \\
& 56 & $5.53^{\mathrm{b}, \mathrm{A}}$ & $5.48^{\mathrm{b}, \mathrm{B}}$ & $4.82^{\mathrm{a}, \mathrm{AB}}$ \\
& 84 & $5.17^{\mathrm{a}, \mathrm{A}}$ & $4.96^{\mathrm{a}, \mathrm{A}}$ & $4.80^{\mathrm{a}, \mathrm{AB}}$ \\
\hline
\end{tabular}

$\overline{{ }^{a-c} \text { Means within the same row with a different lowercase superscript differ }(P<0.05 \text {; comparing the effect of }}$ treatment at a single ripening time).

${ }^{\mathrm{A}-\mathrm{C}}$ Means within the same column (for a particular attribute) with a different uppercase superscript differ $(P$ $<0.05$; comparing the effect of ripening time for a single treatment).

${ }^{1}$ Values represent the means of 4 replicates for each treatment.

values, HLC cheese had significantly $(P<0.05)$ lower sensory firmness values than MLC and LLC cheeses at all ripening times (Table 6). The HLC cheese had higher adhesiveness-of-mass values than the others, and adhesiveness increased significantly during ripening, in agreement with previous studies on LMPS Mozzarella (Moynihan et al., 2014).

At $14 \mathrm{~d}$ of ripening, HLC cheese had a significantly higher acid flavor than MLC and LLC cheese, but fewer differences were observed during the rest of the ripening period (Table 6). The trends in acid flavors were in agreement with the lactic acid levels in these treatments (Figure 1a). Shakeel-Ur-Rehman et al. (2004) found that Cheddar cheese made from low-lactose milk led to lower levels of acid flavor in the cheese. Hou et al. (2014a) found that curd washing (washed curd Cheddar) reduced lactose and lactic acid levels and resulted in cheeses that were characterized as less acid, more buttery, creamier, sweeter, and saltier than varieties that were not curd washed.

\section{Melted Cheese Texture and Sensory Properties}

The lactose-to-casein ratio significantly affected several melted cheese properties, including blister color, strand length, and acid flavor (Table 5). Changes in these melted cheese sensory attributes as a function of ripening time are shown in Table 7. Among the melted cheese surface characteristics evaluated, we observed no differences in the amount of free oil formed, blister quantity, or skinning among the cheeses, except that blister quantity and the amount of free oil in all the cheeses increased with age (results not shown). The LLC cheese had a significantly $(P<0.0001$, Table 5$)$ lower blister color than the HLC and MLC cheeses. Johnson and Olson (1985) found that the residual galactose concentration in Mozzarella cheese was correlated with the degree of browning on the melted cheese on pizzas. The LLC cheese had lower residual galactose levels (Table 3), which likely explained its lower blister color during baking.

Hardness values of the melted cheeses at each time point were similar, and the values decreased significantly during ripening (Table 7). Also, the LLC cheese had significantly lower acid flavor intensity than the HLC cheese throughout ripening (Table 7). The LLC cheese had significantly lower strand length than the HLC throughout ripening (Table 7), probably due to the higher firmness of the unmelted cheese (Table 6; Figure 2). The strand length of all treatments increased significantly throughout ripening. Strand length relates to the ability of the cheese to stretch. The increase in strand length during ripening is probably due to solubilization of INSOL Ca phosphate, which reduces protein crosslinking and ongoing proteolysis (Lucey et al., 2003).

\section{Dynamic Small-Amplitude Oscillatory Rheology}

The lactose-to-casein ratio and age had significant effects on the rheological parameters $\mathrm{LT}_{\max }$ and $\mathrm{LT}=$ 1 values (which are related to meltability) of LMPS Mozzarella cheese (Table 4). The TLT was not affected by the lactose-to-casein ratio (Table 4). The 
LLC cheese had significantly lower $\mathrm{LT}_{\max }$ values than the HLC and MLC cheese at d 14 and 28 of ripening (Figure 3a). As ripening continued, we observed no significant differences between the $\mathrm{LT}_{\max }$ values of any of the treatments. The $\mathrm{LT}_{\max }$ value has been correlated with cheese meltability (Mounsey and O'Riordan, 1999), with higher values indicating a more liquid-like system (Lucey et al., 2003; Govindasamy-Lucey et al., 2005). Hence, LLC cheese had a lower meltability than HLC and MLC cheese at d 14 and 28 of ripening. The temperature where the $\mathrm{LT}=1$ (or the crossover point where $G^{\prime}=G^{\prime \prime}$ ) for the various cheeses during ripening is shown in Figure $3 \mathrm{~b}$. The LT $=1$ is considered the softening or melting point, or where the cheese changes from solid to viscous-like material during heating ( $\mathrm{Gu}-$ nasekaran and $\mathrm{Ak}, 2003$ ). After $28 \mathrm{~d}$ of ripening, the temperature where LT $=1$ was significantly $(P<0.05)$ lower in the HLC cheeses (Figure 3b). The temperature where LT $=1$ decreased significantly in all treatments during ripening, which indicates that with ripening less thermal energy was needed to melt cheese. The increase in $\mathrm{LT}_{\max }$ and decrease in $\mathrm{LT}=1$ values of cheese during ripening is related to the solubilization of INSOL Ca phosphate and ongoing proteolysis (Lucey et al., 2003). The MLC and LLC cheeses were also more meltable (indicated by higher $\mathrm{LT}_{\max }$ ) at the end of the ripening period. In Mozzarella cheese, the temperature at which $\mathrm{LT}=1$ typically decreases during ripening due to ongoing proteolysis (Moynihan et al., 2014) and solubilization of INSOL Ca phosphate (Govindasamy-Lucey et al., 2005).

Guinee et al. (2002) found that with an increase in the $\mathrm{pH}$ of Mozzarella, cheeses took longer to melt and had decreased flowability and stretchability, in agreement with the trends in our study. Cortez et al. (2008) exposed Mozzarella cheese to an ammonia atmosphere, which led to increased cheese $\mathrm{pH}$; the higher $\mathrm{pH}$ resulted in cheese that had reduced melt. In the current study, we observed no difference in proteolysis between cheeses, but the $\mathrm{pH}$ values were significantly higher for MLC and LLC cheese, the likely explanation for their lower melt and harder texture, even though they had lower INSOL Ca phosphate levels than HLC cheese.

\section{CONCLUSIONS}

Lowering the lactose-to-casein ratio in milk resulted in LMPS Mozzarella cheese with lower levels of residual lactose, galactose, and lactic acid, leading to cheese with a higher $\mathrm{pH}$. The LLC cheese exhibited greater solubilization of INSOL Ca phosphate, possibly caused by addition of RO water we used to standardize the

Table 7. Sensory properties of low-moisture, part-skim Mozzarella cheese manufactured from milks with high (HLC), medium (MLC), and low (LLC) lactose-to-casein ratios when melted on pizzas in a forced-air commercial oven during the 84 -d ripening period ${ }^{1}$

\begin{tabular}{|c|c|c|c|c|}
\hline \multirow[b]{2}{*}{ Attribute } & \multirow{2}{*}{$\begin{array}{l}\text { Ripening } \\
\text { time (d) }\end{array}$} & \multicolumn{3}{|c|}{ Treatment } \\
\hline & & HLC & MLC & LLC \\
\hline \multirow[t]{4}{*}{ Blister color } & 14 & $12.65^{\mathrm{b}, \mathrm{A}}$ & $11.55^{\mathrm{b}, \mathrm{A}}$ & $8.84^{\mathrm{a}, \mathrm{A}}$ \\
\hline & 28 & $12.94^{\mathrm{c}, \mathrm{A}}$ & $11.10^{\mathrm{b}, \mathrm{AB}}$ & $8.38^{\mathrm{a}, \mathrm{A}}$ \\
\hline & 56 & $12.79^{\mathrm{c}, \mathrm{A}}$ & $10.20^{\mathrm{b}, \mathrm{BC}}$ & $7.95^{\mathrm{a}, \mathrm{A}}$ \\
\hline & 84 & $12.39^{\mathrm{c}, \mathrm{A}}$ & $9.30^{\mathrm{b}, \mathrm{C}}$ & $8.00^{\mathrm{a}, \mathrm{A}}$ \\
\hline \multirow[t]{4}{*}{ Chewiness } & 14 & $7.09^{\mathrm{ab}, \mathrm{A}}$ & $6.63^{\mathrm{a}, \mathrm{A}}$ & $7.32^{\mathrm{b}, \mathrm{A}}$ \\
\hline & 28 & $6.73^{\mathrm{a}, \mathrm{A}}$ & $7.13^{\mathrm{a}, \mathrm{AB}}$ & $6.81^{\mathrm{a}, \mathrm{AB}}$ \\
\hline & 56 & $6.79^{\mathrm{ab}, \mathrm{A}}$ & $7.31^{\mathrm{b}, \mathrm{BC}}$ & $6.54^{\mathrm{a}, \mathrm{B}}$ \\
\hline & 84 & $6.93^{\mathrm{a}, \mathrm{A}}$ & $7.89^{\mathrm{b}, \mathrm{C}}$ & $7.10^{\mathrm{a}, \mathrm{AB}}$ \\
\hline \multirow[t]{4}{*}{ Hardness } & 14 & $4.22^{\mathrm{a}, \mathrm{A}}$ & $4.20^{\mathrm{a}, \mathrm{A}}$ & $4.62^{\mathrm{a}, \mathrm{A}}$ \\
\hline & 28 & $3.76^{\mathrm{a}, \mathrm{B}}$ & $3.90^{\mathrm{a}, \mathrm{A}}$ & $4.21^{\mathrm{a}, \mathrm{A}}$ \\
\hline & 56 & $3.38^{\mathrm{a}, \mathrm{B}}$ & $3.43^{\mathrm{a}, \mathrm{B}}$ & $3.08^{\mathrm{a}, \mathrm{B}}$ \\
\hline & 84 & $2.40^{\mathrm{a}, \mathrm{C}}$ & $2.66^{\mathrm{a}, \mathrm{C}}$ & $2.93^{\mathrm{a}, \mathrm{B}}$ \\
\hline \multirow[t]{4}{*}{ Acid flavor intensity } & 14 & $4.91^{\mathrm{b}, \mathrm{A}}$ & $4.75^{\mathrm{a}, \mathrm{A}}$ & $4.06^{\mathrm{a}, \mathrm{A}}$ \\
\hline & 28 & $5.05^{\mathrm{b}, \mathrm{A}}$ & $4.73^{\mathrm{ab}, \mathrm{A}}$ & $4.40^{\mathrm{a}, \mathrm{AB}}$ \\
\hline & 56 & $5.15^{\mathrm{b}, \mathrm{A}}$ & $4.82^{\mathrm{ab}, \mathrm{A}}$ & $4.59^{\mathrm{a}, \mathrm{B}}$ \\
\hline & 84 & $4.86^{\mathrm{b}, \mathrm{A}}$ & $4.74^{\mathrm{ab}, \mathrm{A}}$ & $4.32^{\mathrm{a}, \mathrm{AB}}$ \\
\hline \multirow[t]{4}{*}{ Strand length } & 14 & $12.94^{\mathrm{b}, \mathrm{A}}$ & $10.22^{\mathrm{ab}, \mathrm{A}}$ & $7.44^{\mathrm{a}, \mathrm{A}}$ \\
\hline & 28 & $14.25^{\mathrm{b}, \mathrm{A}}$ & $12.58^{\mathrm{ab}, \mathrm{A}}$ & $10.13^{\mathrm{a}, \mathrm{A}}$ \\
\hline & 56 & $19.13^{\mathrm{b}, \mathrm{B}}$ & $17.42^{\mathrm{ab}, \mathrm{B}}$ & $15.31^{\mathrm{a}, \mathrm{B}}$ \\
\hline & 84 & $18.35^{\mathrm{b}, \mathrm{B}}$ & $19.88^{\mathrm{b}, \mathrm{B}}$ & $14.08^{\mathrm{a}, \mathrm{B}}$ \\
\hline
\end{tabular}

${ }^{\mathrm{a}-\mathrm{c}}$ Means within the same row with a different lowercase superscript differ $(P<0.05$; comparing the effect of treatment at a single ripening time).

${ }^{\mathrm{A}-\mathrm{C}}$ Means within the same column (for a particular attribute) with a different uppercase superscript differ $(P$ $<0.05$; comparing the effect of ripening time for a single treatment).

${ }^{1}$ Values represent the means of 4 replicates for each treatment. 

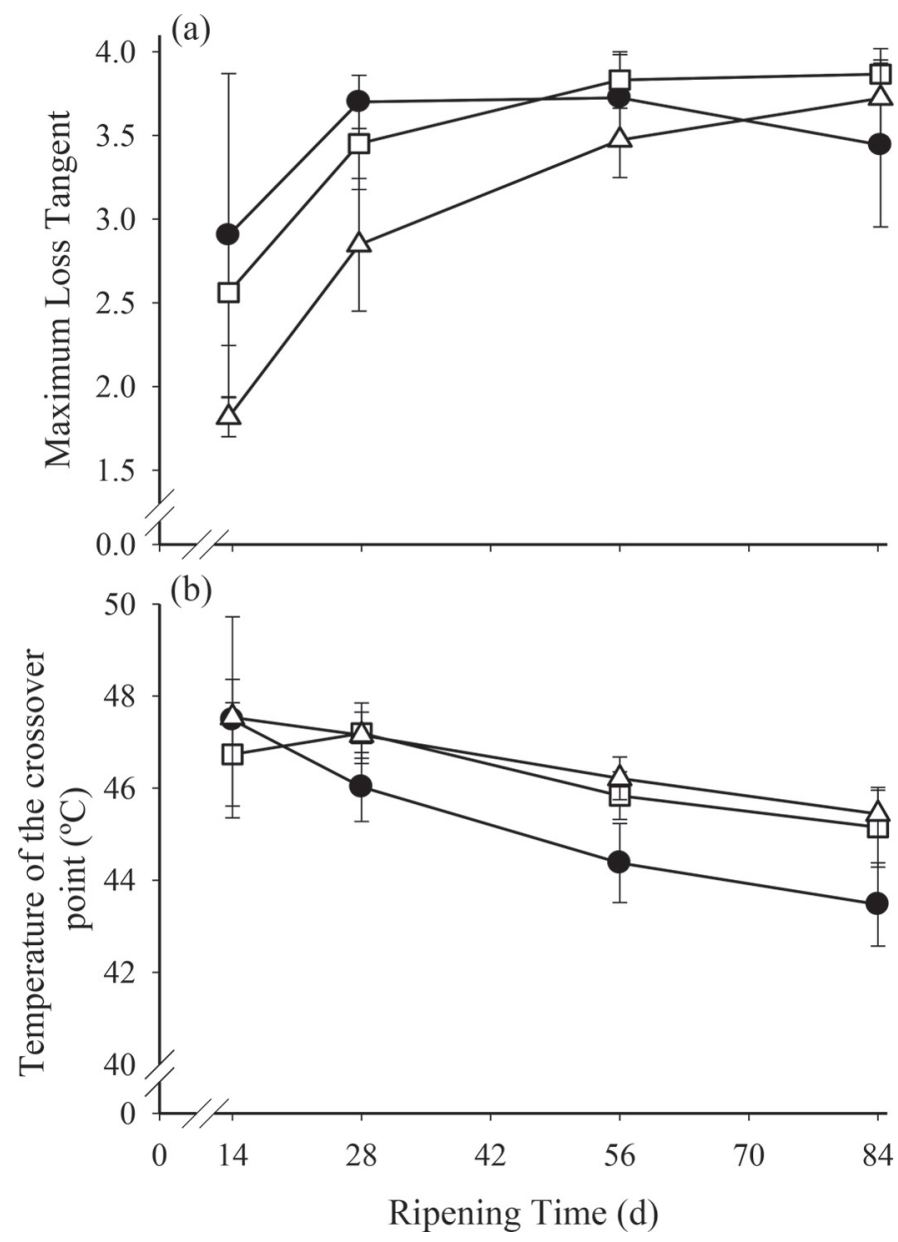

Figure 3. Maximum loss tangent (a) and temperature of the crossover point of the storage and loss moduli curves (or where loss tangent $=1$ ) (b) as a function of ripening time of low-moisture, part-skim Mozzarella cheeses stored at $4^{\circ} \mathrm{C}$ made from milks with varying lactose-to-casein ratios: high $1.8(\bullet)$, medium $1.3(\square)$, and low $1.0(\Delta)$. Values are means of 4 replicates; vertical bars represent SD.

milk composition. Water addition and UF probably resulted in greater losses of soluble $\mathrm{Ca}$ and promoted more solubilization of some INSOL Ca phosphate to re-establish equilibrium between insoluble and soluble forms. Part of the explanation for the higher $\mathrm{pH}$ values observed in the LLC cheese was this Ca equilibrium shift and greater release of phosphate ions (buffering). The LLC cheeses were firmer, chewier, and had lower meltability during ripening due to their higher $\mathrm{pH}$ value, even though they had significantly lower INSOL Ca levels. Controlling the lactose-to-casein ratio provides another way for cheesemakers to optimize the properties of LMPS Mozzarella cheese, which typically has a short shelf life because the cheese becomes excessively soft and soupy. Maintaining a firm texture for a longer period, along with an appropriate melt, could be beneficial to Mozzarella cheese makers. This novel approach of standardizing the lactose content of the cheesemilks could be used to help produce LMPS Mozzarella with improved properties, such as reduced acid flavor and lower blister color on baking. Standardization of the lactose-to-casein ratio of milk has the potential to reduce $\mathrm{pH}$ variability and thereby produce pasta filata cheeses of more consistent textural and functional properties.

\section{ACKNOWLEDGMENTS}

The authors gratefully acknowledge the support of a travel bursary from the Fulbright Commission of Ireland. The authors thank personnel from Wisconsin Center for Dairy Research and University of Wisconsin Dairy Plant (Madison, WI) for their assistance and support in cheese making, analytical work, and sensory analysis. The financial support of the Wisconsin Center for Dairy Research Industry Team (Madison, WI) is greatly appreciated. We also thank Cargill Texturizing Solutions (Waukesha, WI) and Chr. Hansen Inc. (Milwaukee, WI) for their donation of the starter cultures and coagulants, respectively, used in this study.

\section{REFERENCES}

AOAC International. 2000. Official Methods for Analysis. 17th ed. AOAC International, Arlington, VA.

Bourne, M. C. 1978. Texture profile analysis. J. Food Technol. 32:6266.

Chen, C., D. Wolle, and D. Sommer. 2009. Mozzarella. Pages 459-487 in The Sensory Evaluation of Dairy Products. 2nd ed. Springer Science and Business Media, New York, NY.

Cortez, M. A. S., M. M. Furtado, M. L. Gigante, and P. S. Kindstedt. 2008. Effect of $\mathrm{pH}$ on characteristics of low-moisture Mozzarella cheese during refrigerated storage. J. Food Sci. 73:S443-448.

Everard, C. D., D. J. O'Callaghan, T. V. Howard, C. P. O'Donnell, E. M. Sheehan, and C. M. Delahunty. 2006. Relationships between sensory and rheological measurements of texture in maturing commercial Cheddar cheese over a range of moisture and $\mathrm{pH}$ at the point of manufacture. J. Texture Stud. 37:361-382.

Ferrer, M. A., M. Alexander, and M. Corredig. 2011. Does ultrafiltration have a long lasting effect on the physico-chemical properties of the casein micelles? Dairy Sci. Technol. 91:151-170.

Govindasamy-Lucey, S., J. J. Jaeggi, A. L. Bostley, M. E. Johnson, and J. A. Lucey. 2004. Standardization of milk using cold ultrafiltration retentates for the manufacture of Parmesan cheese. J. Dairy Sci. 87:2789-2799.

Govindasamy-Lucey, S., J. J. Jaeggi, M. E. Johnson, T. Wang, and J. A. Lucey. 2005. Use of cold ultrafiltration retentates for standardization of milks for pizza cheese: Impact on yield and functionality. Int. Dairy J. 15:941-955.

Govindasamy-Lucey, S., J. J. Jaeggi, M. E. Johnson, T. Wang, and J. A. Lucey. 2007. Use of cold microfiltration retentates produced with polymeric membranes for standardization of milks for manufacture of pizza cheese. J. Dairy Sci. 90:4552-4568.

Green, W. C., and K. K. Park. 1980. Comparison of AOAC, microwave and vacuum oven methods for determining total solids in milk. J. Food Prot. 43:728-783.

Guinee, T. P., E. P. Feeney, M. A. E. Auty, and P. F. Fox. 2002. Effect of $\mathrm{pH}$ and calcium concentration on some textural and functional properties of Mozzarella cheese. J. Dairy Sci. 85:1655-1669. 
Gunasekaran, S., and M. M. Ak. 2003. Cheese Rheology and Texture. CRC Press LLC, Boca Raton, FL.

Hassan, A., M. E. Johnson, and J. A. Lucey. 2004. Changes in the proportions of soluble and insoluble calcium during the ripening of Cheddar cheese. J. Dairy Sci. 87:854-862.

Hou, J., J. A. Hannon, P. L. H. McSweeney, T. P. Beresford, and T. P. Guinee. 2012. Effect of curd washing on composition, lactose metabolism, $\mathrm{pH}$, and the growth of non-starter lactic acid bacteria in full-fat Cheddar cheese. Int. Dairy J. 25:21-28.

Hou, J., J. A. Hannon, P. L. H. McSweeney, T. P. Beresford, and T. P. Guinee. 2014a. Effect of curd washing on cheese proteolysis, texture, volatile compounds and sensory grading in full-fat Cheddar cheese. Int. Dairy J. 34:190-198.

Hou, J., P. L. H. McSweeney, T. P. Beresford, and T. P. Guinee. 2014b. Effect of curd washing on the properties of reduced-calcium and standard-calcium Cheddar cheese. J. Dairy Sci. 97:5983-5999.

Huffman, L. M., and T. Kristoffersen. 1984. Role of lactose in Cheddar cheese manufacturing and ripening. N. Z. J. Dairy Sci. Technol. 19:151-162.

Johnson, M. E., C. M. Chen, and J. J. Jaeggi. 2001. Effect of rennet coagulation time on composition, yield and quality of reduced-fat Cheddar cheese. J. Dairy Sci. 84:1027-1033.

Johnson, M. E., and J. A. Lucey. 2006. Calcium: a key factor in controlling cheese functionality. Aust. J. Dairy Technol. 61:147-153.

Johnson, M. E., and N. F. Olson. 1985. Nonenzymatic browning of Mozzarella cheese. J. Dairy Sci. 68:3143-3147.

Kindstedt, P. S., J. J. Yun, D. M. Barbano, and K. L. Larose. 1995 Mozzarella cheese: Impact of coagulant concentration on chemical composition, proteolysis, and functional properties. J. Dairy Sci. $78: 2591-2597$

Kuchroo, C. N., and P. F. Fox. 1982. Soluble nitrogen in Cheddar cheese: Comparison of extraction procedures. Milchwissenschaft $37: 331-335$.

Lawrence, R. C., L. K. Creamer, and J. Gilles. 1987. Texture development during cheese ripening. J. Dairy Sci. 70:1748-1760.

Lawrence, R. C., H. A. Heap, and J. Gilles. 1984. A controlled approach to cheese technology. J. Dairy Sci. 67:1632-1645.

Lee, M.-R., M. E. Johnson, S. Govindasamy-Lucey, J. J. Jaeggi, and J. A. Lucey. 2010. Insoluble calcium content and rheological properties of Colby cheese during ripening. J. Dairy Sci. 93:1844-1853.

Lee, M.-R., M. E. Johnson, S. Govindasamy-Lucey, J. J. Jaeggi, and J. A. Lucey. 2011. Effect of different curd-washing methods on the insoluble calcium content and rheological properties of Colby cheese during ripening. J. Dairy Sci. 94:2692-2700.

Lee, M.-R., M. E. Johnson, and J. A. Lucey. 2005. Impact of modifications in acid development on the insoluble calcium content and rheological properties of Cheddar cheese. J. Dairy Sci. 88:37983809.

Li, Y., and M. Corredig. 2014. Calcium release from milk concentrated by ultrafiltration and diafiltration. J. Dairy Sci. 97:5294-5302.

Lucey, J. A., and P. F. Fox. 1993. Importance of calcium and phosphate in cheese manufacture: A review. J. Dairy Sci. 76:1714-1724.

Lucey, J. A., B. Hauth, C. Gorry, and P. F. Fox. 1993. The acid-base buffering properties of milk. Milchwissenschaft 48:268-272
Lucey, J. A., M. E. Johnson, and D. S. Horne. 2003. Perspectives on the basis of the rheology and texture properties of cheese. J. Dairy Sci. 86:2725-2743.

Lucey, J. A., R. Mishra, A. Hassan, and M. E. Johnson. 2005. Rheological and calcium equilibrium changes during the ripening of Cheddar cheese. Int. Dairy J. 15:645-653.

Marshall, R. T. 1992. Standard Methods for the Examination of Dairy Products. 16th ed. American Public Health Association, Washington, DC.

McMahon, D. J., B. Paulson, and C. J. Oberg. 2005. Influence of calcium, $\mathrm{pH}$, and moisture on protein matrix structure and functionality in direct-acidified nonfat Mozzarella cheese. J. Dairy Sci. 88:3754-3763

Meilgaard, M. M., G. V. Civille, and B. T. Carr. 1999. Selection and training of panel members. Pages 174-176 in Sensory Evaluation Techniques. 3rd ed. CRC Press, Boca Raton, FL.

Mishra, R., S. Govindasamy-Lucey, and J. A. Lucey. 2005. Rheological properties of rennet-induced gels during the coagulation and cutting process: Impact of processing conditions. J. Texture Stud. $36: 190-212$.

Mounsey, J. S., and E. D. O'Riordan. 1999. Empirical and dynamic rheological data correlation to characterize melt characteristics of imitation cheese. J. Food Sci. 64:701-703.

Moynihan, A. C., S. Govindasamy-Lucey, J. J. Jaeggi, M. E. Johnson, J. A. Lucey, and P. L. H. McSweeney. 2014. Effect of camel chymosin on texture, functionality, and sensory properties of lowmoisture, part-skim Mozzarella cheese. J. Dairy Sci. 97:85-96.

Osaili, T. M., M. M. Ayyash, A. A. Al-Nabulsi, R. R. Shaker, and N P. Shah. 2010. Effect of curd washing level on the proteolysis and functionality of low-moisture Mozzarella cheese made with galactose fermenting cultures. J. Food Sci. 75:C406-412.

Ramkumar, C., O. H. Campanella, P. J. Watkinson, R. J. Bennett, and L. K. Creamer. 1998. The effects of $\mathrm{pH}$ and time on rheological changes during early cheese maturation. J. Texture Stud. 29:633-644.

SAS Institute. 2004. SAS User's Guide: Statistics. Version 9.1. SAS Inst. Inc., Cary, NC.

Shakeel-Ur-Rehman, D. Waldron, and P. F. Fox. 2004. Effect of modifying lactose concentration in cheese curd on proteolysis and in quality of Cheddar cheese. Int. Dairy J. 14:591-597.

Sousa, M. J., Y. Ardo, and P. L. H. McSweeney. 2001. Advances in the study of proteolysis during cheese ripening. Int. Dairy J. 11:327345 .

Turner, K. W., and T. D. Thomas. 1980. Lactose fermentation in Cheddar cheese and the effect of salt. N. Z. J. Dairy Sci. Technol. $15: 265-276$

Watkinson, P., C. Coker, R. Crawford, C. Dodds, K. Johnston, A McKenna, and N. White. 2001. Effect of cheese $\mathrm{pH}$ and ripening time on model cheese textural properties and proteolysis. Int. Dairy J. 11:455-464.

Zeppa, G., L. Conterno, and V. Gerbi. 2001. Determination of organic acids, sugars, diacetyl, and acetoin in cheese by high-performance liquid chromatography. J. Agric. Food Chem. 49:2722-2726. 